\title{
The Jesuit Order as a Synagogue of Jews
}




\title{
Studies in Medieval and Reformation Traditions
}

\author{
Edited by \\ Andrew Colin Gow \\ Edmonton, Alberta \\ In cooperation with \\ Sylvia Brown, Edmonton, Alberta \\ Falk Eisermann, Berlin \\ Berndt Hamm, Erlangen \\ Johannes Heil, Heidelberg \\ Susan C. Karant-Nunn, Tucson, Arizona \\ Martin Kaufhold, Augsburg \\ Jürgen Miethke, Heidelberg \\ M.E.H. Nicolette Mout, Leiden \\ Christopher Ocker, San Anselmo and Berkeley, California
}

Founding Editor

Heiko A. Oberman $\dagger$

VOLUME 146 


\section{The Jesuit Order \\ as a Synagogue of Jews}

Jesuits of Jewish Ancestry and Purity-of-Blood Laws in the Early Society of Jesus

By

Robert Aleksander Maryks

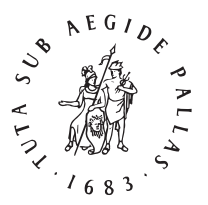

B R I L L 
This is an open access title distributed under the terms of the CC-BY-NC License, which permits any non-commercial use, distribution, and reproduction in any

An electronic version of this book is freely available, thanks to the support of libraries working with Knowledge Unlatched. More information about the initiative can be found at www.knowledgeunlatched.org.

On the cover: The View of Toledo. El Greco (Domenikos Theotokopoulos) (Greek, 1541-1614). The Metropolitan Museum of Arts, New York City.

Library of Congress Cataloging-in-Publication Data

Maryks, Robert Aleksander

The Jesuit Order as a synagogue of Jews : Jesuits of Jewish ancestry and purity-of-blood laws in the early Society of Jesus / by Robert Aleksander Maryks.

p. cm. - (Studies in medieval and Reformation traditions ; v. 146)

Includes bibliographical references (p. ) and index.

ISBN 978-90-04-17981-3 (hardback : alk. paper) 1. Jesuits-Membership-

History-16th century. 2. Jesuits-Membership-History-17th century.

3. Marranos-History-16th century. 4. Marranos-History-17th century.

5. Antisemitism-Iberian Peninsula-History. 6. Race discrimination-Religious aspects-Christianity. 7. Iberian Peninsula-Ethnic relations. I. Title. II. Series.

BX3706.A2.M37 2009

271'.53046089924-dc22

2009035704

ISSN $1573-4188$

ISBN 9789004179813

Copyright 2010 by Koninklijke Brill nv, Leiden, The Netherlands.

This work is published by Koninklijke Brill Nv. Koninklijke Brill NV incorporates the imprints Brill, Brill Hes \& De Graaf, Brill Nijhoff, Brill Rodopi and Hotei Publishing.

Koninklijke Brill NV reserves the right to protect the publication against unauthorized use and to authorize dissemination by means of offprints, legitimate photocopies, microform editions, reprints, translations, and secondary information sources, such as abstracting and indexing services including databases. Requests for commercial re-use, use of parts of the publication, and/or translations must be addressed to Koninklijke Brill NV.

This book is printed on acid-free paper and produced in a sustainable manner. 
Rodzicom moim drogim 
R. Maryks - 9789047444114

Downloaded from Brill.com04/26/2023 12:01:05AM via free access 


\section{CONTENTS}

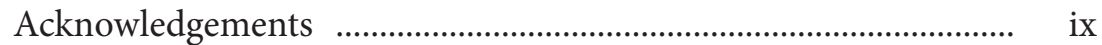

List of Abbreviations ……….................................................... xi

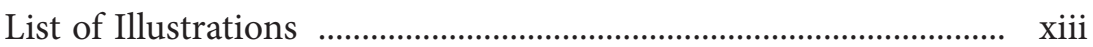

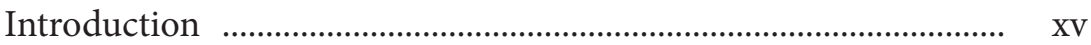

Chapter One The Historical Context of Purity-of-Blood

Discrimination (1391-1547) ......................................................... 1

Sentencia-Estatuto of Pero de Sarmiento (1449) $\quad$........................... 2

Alonso de Cartagena and Alonso de Oropesa ........................... 4

Purity-of-blood statutes of Archbishop Silíceo (1547) .............. 29

Defensio Toletani Statuti of Diego de Simancas (1573) ............. 31

Chapter Two Early Jesuit Pro-converso Policy (1540-72) ........ 41

Ignatius of Loyola as a "deep spiritual Semite" .......................... 42

Jerónimo Nadal's opposition to the purity-of-blood

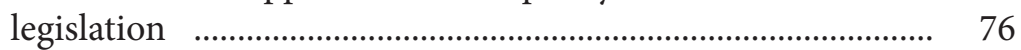

The converso triumvirate: the election of Diego Laínez ........... 90

Francisco de Borja's infinite love of conversos .......................... 100

Chapter Three Discrimination Against Jesuits of Jewish Lineage (1573-93) ...................................................................... 117

Italo-Portuguese anti-converso lobby at General

Congregation 3 .................................................................... 120

Everard Mercurian's "house cleansing" ………………............... 123

Memorialistas' revolt against Rome ............................................ 125

Benedetto Palmio's converso-phobic memorial ......................... 129

Acquaviva's discriminatory measures .......................................... 143

Chapter Four Jesuit Opposition to the Purity-of-blood

Discrimination (1576-1608) ..................................................... 159

Antonio Possevino ................................................................. 162

Diego de Guzmán ................................................................. 182

Pedro de Ribadeneyra ................................................................ 187

García Girón de Alarcón .......................................................... 190

Juan de Mariana ........................................................................ 212 
viii

CONTENTS

Conclusion $\quad$................................................................................ 215

Appendix I ............................................................................... 219

Appendix II ............................................................................. 257

Bibliography .............................................................................. 261

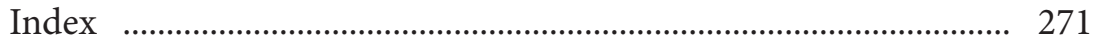




\section{ACKNOWLEDGEMENTS}

I express my particular gratitude to the scholars who have generously assisted me with their insightful comments and suggestions in the process of writing the present book. These include André Aciman, Miriam Bodian, Jonathan Boyarin, Richard F. Gyug, Ignacio Echarte Oñate, Kimberly Lynn Hossain, Francisco de Borja Medina, Thomas M. McCoog, Marc Rastoin, James W. Reites, Jean-Pierre Sonnet, and Alison P. Weber.

I owe much to the Jesuits of the Jesuit Historical Institute in Rome, Thomas M. McCoog and James F.X. Pratt for their friendly support and generous hospitality during my work there. The research in the archives progressed efficiently thanks also to the serene and accommodating spirit of the staff of the Institute, especially Nicoletta Basilotta and Mauro Brunello. I also thank Jill G. Thomas, the Jesuitana Librarian at John J. Burns Library of Boston College, who graciously and competently assisted me in finding and obtaining for publication the illustrations contained in the present book.

While writing this book in New York City, the help of the staff at Fordham University Libraries in collecting secondary sources was indispensable. I thank especially Christine Campbell, Helena Cunniffe, Betty Garity, and Charlotte Labbe.

A PCS-CUNY Research Grant provided the financial support necessary to do research in the archives of Rome in 2008, and Andrea Finkelstein, the acting chairperson in the History Department at Bronx Community College of the City University of New York, generously accommodated my teaching schedule to fit it into my writing project. 
R. Maryks - 9789047444114

Downloaded from Brill.com04/26/2023 12:01:05AM via free access 


\section{LIST OF ABBREVIATIONS}

$\begin{array}{ll}* & \text { born } \\ \dagger & \text { died } \\ \text { ACA } & \text { Archivo de la Corona de Aragón, Barcelona } \\ \text { ARSI } & \text { Archivo Histórico Nacional, Madrid } \\ & \text { Archivio Romano Societatis Iesu (the Jesuit Archives in } \\ \text { AHSI } & \text { Rome) } \\ \text { c. } & \text { Archivum Historicum Societatis Iesu (periodical) } \\ \text { Chron. } & \text { Chrca } \\ \text { Const. } & \text { Constitutions } \\ \text { DEI } & \text { Diccionario de Espiritualidad Ignaciana } \\ \text { DHCJ } & \text { Diccionario Histórico de la Compañía de Jesús } \\ \text { Epp. } & \text { Epistulae } \\ \text { f. } & \text { folio } \\ \text { ff. } & \text { folios } \\ \text { Fontes narr. } & \text { Fontes narrativi (MHSI) } \\ \text { GC } & \text { General Congregation } \\ \text { MHSI } & \text { Monumenta Historica Societatis Iesu } \\ \text { Mon } & \text { Monumenta } \\ \text { Opp. NN. } & \text { Opera Nostrorum } \\ \text { r. } & \text { reigned } \\ \text { S.J. (S.I.) } & \text { Societatis Iesu (of the Society of Jesus) } \\ \text { See also Monumenta Historica Societati Iesu (MHSI) in Bibliography, } \\ \text { where the abbreviations for the collection's volumes are provided. }\end{array}$


R. Maryks - 9789047444114

Downloaded from Brill.com04/26/2023 12:01:05AM via free access 


\section{LIST OF ILLUSTRATIONS}

Map of the Iberian Peninsula in 1492

xxxiii

Fig. 1. Pedro de Ribadeneyra as the biographer of Ignatius of Loyola

Fig. 2. Ignatius of Loyola incarcerated by the Inquisition in Alcalá

Fig. 3. Íñigo accused of seducing students at the University of Paris

Fig. 4. Iñigistas in Paris: the nucleus of the future Society of Jesus

Fig. 5. Diego Laínez (1512-65), the most prominent converso Jesuit

Fig. 6. Ignatius of Loyola converting a Jew

Fig. 7. Jerónimo Nadal (1507-80) —Loyola’s plenipotentiary emissary

Fig. 8. Nicolás Bobadilla (c. 1509-90)—the converso opponent of the "converso triumvirate"

Fig. 9. The Italian Jesuit historian Francesco Sacchini (1570-1625)

Fig. 10. Bl. Ignacio de Azevedo (1526-70) - the martyred missionary of Brazil

Fig. 11. Francisco de Toledo [Herrera] (1532-96) - the first Jesuit cardinal

Fig. 12. Francisco Suárez [de Toledo] (1548-1617)—the converso supporter of the anti-converso legislation

Fig. 13. Alfonso Salmerón (1515-85)—an influential opponent of the converso discrimination

Fig. 14. Map of seventeenth-century Vietnam

Fig. 15. Engravings from the Vestigatio arcani sensus in Apocalypsi (Antwerp, 1614) by Luis del Alcázar (1554-1613)

Fig. 16. The Italian Jesuit writer and diplomat Antonio Possevino (1533-1611)

Fig. 17. Juan de Mariana (1536-1624)—-the Spanish avatar of Titus Livius 
R. Maryks - 9789047444114

Downloaded from Brill.com04/26/2023 12:01:05AM via free access 